\title{
Como o curso mudou minha carreira e contribuiu para a Nova Voice
}

\author{
How the course changed my career \\ and contributed to the new Voice \\ Cómo el curso cambió mi carrera \\ y contribuyó a la nueva Voice
}

Norma Alcântara ${ }^{7}$

Como um tsunami que avisa sua chegada, com o recuo das águas, a internet e as tecnologias da informação sinalizavam aos profissionais da comunicação, no final da década de 1990, que uma grande revolução, já em andamento em outros segmentos, iria também mudar os rumos dos negócios de comunicação. O impacto ocorreu de forma mais dramática para empresas que não se transformaram. Como decorrência desses processos, assistimos, nos últimos cinco anos, a um movimento contraditório de crescimento de parte das agências, em especial as associadas às multinacionais, e de fechamento de dezenas de outras.

Àquela época, já estava claro que os serviços tradicionais de Assessoria de Imprensa ocupariam, em um futuro próximo, com as mudanças trazidas pela tecnologia, posição menos central no negócio das agências, porque as organizações passariam a demandar novas e mais complexas soluções de comunicação.

Para enfrentar esse cenário, à frente da Voice Comunicação Institucional, decidi buscar aquilo que só a universidade poderia me oferecer - o debate sem

7 Graduada em Jornalismo pela Faculdade Cásper Líbero e especialista em Gestão Estratégica em Comunicação e Relações Públicas pela ECA-USP, é diretora-geral dos núcleos de atendimento da Voice Comunicação Institucional. Coautora dos livros Imprensa na berlinda: a fonte pergunta (Rideel) e Relações assessorias \& redações, publicado pelo Sindicato dos Jornalistas do Estado de São Paulo. Foi integrante da Turma 2001 do Gestcorp, tendo defendido a monografia Relações das fontes com a mídia: desvendamento para o debate crítico. E.mail: nalcantara@voice.com.br. 
fronteiras, a livre circulação de ideias, o conhecimento acumulado que se recicla permanentemente e não fórmulas fechadas e consagradas pelo fazer profissional. No início de 2000, passei a integrar uma das primeiras turmas do curso de Pós-Graduação Lato Sensu de Gestão Estratégica da Comunicação Organizacional e Relações Públicas, criado e coordenado, na ECA-USP, pela Profa. Dra. Margarida Maria Krohling Kunsch.

Entre nossos professores estavam a própria Margarida Kunsch, com sua teoria da comunicação integrada; Manuel Carlos Chaparro, com sua teoria da "revolução das fontes"; Paulo Nassar, que se tornaria líder de uma grande mudança na Aberje; Heloiza Helena G. de Matos, com sua visão prática sobre a integração do planejamento da Comunicação Institucional e da Comunicação Mercadológica; Elizabeth Correa Saad, cujos estudos sobre a Comunicação Digital e seus usos institucionais mostraram objetivamente o impacto das tecnologias na comunicação e no relacionamento das organizações com os públicos; e, por fim, e entre tantos outros, Mitsuro Higuchi Yanaze, que anteviu a questão da mensuração como tema central nos debates da comunicação.

Meu trabalho de conclusão do curso inspirou a publicação do livro Imprensa na berlinda: a fonte pergunta, com Carlos Chaparro e Wilson Garcia, pela Editora Rideel, hoje referência bibliográfica dos cursos de media training. Mais ou menos nesta época, a Voice integrou o grupo de empresas que fundaram a Associação Brasileira ds Agências de Comunicação (Abracom).

A propósito da reflexão provocada por este depoimento, posso afirmar que o curso criado pela professora Margarida Kunsch contribuiu para a nova configuração do negócio da Comunicação Institucional da atualidade e influenciou diretamente na reformulação do negócio da Voice.

Pude converter, paulatinamente, os novos conhecimentos adquiridos no curso e as reflexões que provocou em práticas, conteúdos e ferramentas para um reposicionamento da Voice. Éramos uma empresa com serviços de Assessoria de Imprensa e concluímos que precisávamos ampliar nosso escopo de atuação.

Já entre 2003 e 2004, identificamos que teríamos de converter as ações adotadas no mundo real para o virtual. Montamos a área de Conteúdo \& Novas Mídias, para desenvolver soluções de comunicação na web. Na ocasião, em parceria com o portal Comunique-se, fomos pioneiros na utilização das coletivas on-line.

Os demais stakeholders começaram a ser considerados paulatina e formalmente, de forma mais ampla, em nossos programas. Criamos a Área de Relações Institucionais, com foco em Relações Públicas. Introduzimos inicialmente serviços de Comunicação Interna. Mudamos nosso contrato social, de Assessoria de Imprensa para agência de Relações Públicas e nos filiamos ao Conselho Regional de Profissionais de Relações Públicas (Conrerp). 
Formatamos metodologicamente técnicas de alinhamento e posicionamento, que já utilizávamos no treinamento de fontes e que, depois, entrariam para o portfólio da nova Área de Consultoria, juntamente com serviços de Administração de Crises e Media Training. E enriquecemos nosso time interno multidisciplinar com consultores externos, que vinham atender à nova configuração.

Essas mudanças sinalizaram a nossos clientes e ao mercado que a Voice deixava a posição restrita de uma Assessoria de Imprensa e se transformava em uma agência de Comunicação Institucional, uma PR Agency. Foi uma transformação lenta e cuidadosa, ao longo de cinco anos, hoje consolidada e reconhecida.

Inúmeras vezes me perguntam o que fizemos para levar a inovação para nosso time - formado por profissionais bem preparados e, por isso, cobiçados e atraídos pela concorrência. $\mathrm{O}$ que havia sido feito para reciclar nossa agência de forma tão consistente em meio a tanta revolução? Jamais deixei de dar o caminho do ouro: vá beber na fonte da professora Margarida. 